\title{
Thematic Content Analysis of Graduate Studies on Authentic Learning in Turkey
}

\section{Zekeriya Fatih İNEÇ * , Yeşim BOZKURT **}

\section{Received date: 01.03.2021}

Accepted date: 15.05 .2021

\begin{abstract}
This study aims to investigate the general trends of graduate studies on authentic learning with a holistic approach. Graduate theses about authentic learning reached from the Turkish Council of Higher Education (CoHE) National Thesis Center Database were examined in this study. Thirtyone of these theses were included in the research. The study, with its qualitative research approach, was carried out by synthesizing the findings determined by thematic content analysis. The findings showed that authentic learning was mostly used on an activity basis in the studies. Thus the studies aimed to examine authentic learning's effect on the relevant variables. The findings showed that while the dependent variables were investigated in the quantitative dimension, especially the skills were examined in the qualitative dimension. They also revealed that the studies focused on Science Education much, adopted mixed approaches, used purposeful and random sampling types, and run especially qualitative data analysis in data analysis. The findings also indicated that the average duration of the studies was eight weeks, trip and brainstorming were among the most used teaching techniques, the discussion was extensively used among the methods, and scenario-based learning was used most among the approaches. It was observed that mostly forms, then performance evaluation and scales, and then tests were adopted as measurement - evaluation tools, and the results obtained were mostly positive in these studies.
\end{abstract}

Keywords: Authentic learning, graduate studies, thematic content analysis, meta-synthesis.

\footnotetext{
*(D) Erzincan Binali Yıldırım Üniversitesi, Temel Eğitim, Erzincan, Türkiye, fatihinec@erzincan.edu.tr

**(D) Erzincan Binali Yıldırım Üniversitesi, Türkçe ve Sosyal Bilimler, Erzincan, Türkiye, yesimbozkurt88@hotmail.com
} 


\title{
Türkiye'de Otantik Öğrenme Üzerine Gerçekleştirilen Lisansüstü Çalışmalara Yönelik Tematik İçerik Analizi
}

\author{
Zekeriya Fatih İNEÇ * , Yeşim BOZKURT **
}

Geliş tarihi: 01.03.2021

Kabul tarihi: 15.05.2021

\section{Öz}

$\mathrm{Bu}$ araştırmanın amacl, otantik öğrenmenin incelendiği lisansüstü tezlerin genel eğilimlerini bütüncül bir yaklaşımla analiz ederek değerlendirmektir. Bu doğrultuda otantik öğrenme ile ilişkilendirilen lisansüstü tezler, Yüksek Öğretim Kurumu Ulusal Tez Merkezi üzerinden incelenmiş ve bu tezlerden otuz bir tanesi araştırmaya dahil edilmiștir. Nitel araştırma yaklaşımının benimsendiği çalışma, tematik içerik analiziyle tespit edilen bulguların sentezlenmesiyle gerçekleştirilmiştir. Ulaşılan bulgular, çalışmalarda otantik öğrenmenin çoğunlukla etkinlik temelinde kullanıldığını böylece ilgili değişkenlere etkisinin incelenmesinin amaçlandığını göstermiştir. Ayrıca bağımlı değişkenlerin nicel boyutunda özellikle becerilerin, nitel boyutunda ise görüşlerin incelendiğini göstermiştir. Yapılan çalışmaların Fen Bilgisi Eğitimi'nde yoğunlaştığı, karma yaklaşımların benimsendiğini, örnekleme türünün amaçlı ve rastgele örnekleme olduğunu, veri analizinde özellikle nitel veri analiz türlerinin tercih edildiğini ortaya koymuştur. Yapılan çalışma sürelerinin genelde sekiz hafta olduğunu, öğretim tekniklerinden en çok gezi ile beyin fırtınasının kullanıldığını, yöntemlerden tartışmanın, öğrenme yaklaşımlarından ise senaryo tabanlı öğrenmenin daha çok kullanıldığını göstermiştir. Ölçme-değerlendirme araçları olarak çoğunlukla formların, ardından performans değerlendirme ve ölçeklerin, sonrasında ise testlerin benimsendiği ve elde edilen sonuçların ise büyük oranda olumlu olduğu gözlemlenmiştir.

Anahtar kelimeler: Otantik öğrenme, lisansüstü çalışmalar, tematik içerik analizi, meta-sentez.

\footnotetext{
*(D) Erzincan Binali Yıldırım Üniversitesi, Temel Eğitim, Erzincan, Türkiye, fatihinec@erzincan.edu.tr

**(D) Erzincan Binali Yıldırım Üniversitesi, Türkçe ve Sosyal Bilimler, Erzincan, Türkiye, yesimbozkurt88@hotmail.com
} 


\section{Introduction}

Human beings are constantly interacting with their environment from the moment they are born. As a result, it is the behavior of the learnings it obtains. When learning is taken into this context, it is seen that it is defined differently, but the concepts of human and interaction in focus do not change. As a matter of fact, learning is expressed by Senemoğlu (2015) as a relatively permanent patterned behavior change that occurs as a result of a certain level of interaction with the individual's environment. Terry (2011) explains learning as a change in one's experiences with life and ability to develop behavior.

Strategies are used to perform learning in the context of a systematic process. The strategies that arise by analyzing the learners' learning status focus on the organization of the learning process (Özer, 2008). The Ministry of National Education of Turkey (MoNE) also aims to educate individuals who can solve problems, think critically, entrepreneurial, determined, have communication skills, empathize, contribute to society and culture with their learning strategies in line with their General Goals (MoNE, 2018). One of the strategies accepted in this context is authentic learning (Bektaş \& Horzum, 2014), while its essence is associated with its authentic concept.

Authentic concept "has not lost its quality, protecting its essence" (İneç, 2020, p.17). According to the Turkish Language Association's Contemporary Turkish Dictionary, authentic means "the original features that have been present since the past" (TLA, 2020). It is seen that the concept of authenticity is explained as being original and unique (Bektaş \& Horzum, 2014) and non-artificial, close to the real features and bearing the characteristics it has had since time (Aynas, 2018). Designing teaching according to the nature of this concept is defined as authentic learning and is considered a learning strategy (İneç, 2020, p.19; İneç, 2021).

In the relevant literature, there are many definitions and evaluations related to authentic learning. While the use of original products in learning processes in various studies is considered authentic learning, the nature of authentic learning as a strategy is seen as a specific process. When authentic learning is considered within this framework, it is expressed as a learning situation in which learners solve complex real-world problems in learning environments designed through multiple disciplines (Lombardi, 2007). On the other hand, authentic learning, designed in a structure suitable for structuring understanding, is a learning-centered strategic approach that enables learners to be active through real-life problems (İneç, 2017; İneç, 2021).

The various teaching methods and techniques in the teaching design process ensure that authentic learning is evaluated as a strategy. More simply, various teaching methods and techniques are included in the learning process by teaching designers to use authentic learning in the context of real life. In this context, authentic learning is applied as a strategy (İneç \& Akpınar, 2017) through a scenario, evidence, and research-based learning, as well as project and problembased and situational learning (Knobloch, 2003). Bektaş and Horzum (2014) state that problem, project, event-based learning methods and collaborative, situational learning, and cognitive apprenticeship techniques are used in the realm of authentic learning.

Authentic learning is not seen as a new learning strategy but as one that stretches from the past to the present and is used to train apprentices (Bektaş \& Horzum, 2014). Because this strategy is seen as a pedagogical approach that allows students to explore, explain, discuss and meaningfully structure the relationships in real-world problem and project contexts associated with their real- 
life and participate in real-life problems, and to achieve this, the master-apprentice relationship is transformed into a teacher-student relationship (İneç, 2017). While learners find solutions to real-world problems for this purpose, they reach a certain level of knowledge, skills, and equipment. However, authentic activities and evaluations are applied with authentic tasks, and teachers guide them in this process (Koçyiğit \& Zembat, 2013). However, the authentic learning environment is designed with a learning focus and allows access to different disciplines in informal settings. At this stage, learners have lifelong access to information with a real context in cooperation as a scientific apprentice (Callison \& Lamb, 2004).

When the graduate studies on authentic learning in Turkey are examined, some of these theses are created only through objects or materials associated with real life, some of them by supporting the learning process of one or more of the authentic learning components. However, it is understood in line with the relevant literature that authentic learning cannot be carried out in this way, by nature, but should be supported by experimental processes that are complex beyond that. This is ensured by using authentic learning as a strategy in learning processes. Therefore, academic studies on authentic learning should guide the new studies to be carried out. In addition, it is thought that the study will make a significant contribution to the scientific literature in our country in terms of accurate perception of the nature of authentic learning. This study is carried out to examine the thematic examination of graduate studies on authentic learning in Turkey. For this purpose, authentic learning literature reached through the Council of Higher Education (CoHE) National Thesis Center database was examined and analyzed in terms of general trends of 31 graduate theses in which authentic learning was evaluated as a strategy. The sub-problems of the problem sentence of the research designed for these purposes are as follows:

1) What are the objectives of the studies on authentic learning?

2) What are the dependent variables examined in the studies?

3) What are the branches of science in which studies are carried out?

4) What are the research methods and patterns in which the studies are conducted?

5) How were the samples and workgroups of the studies created?

6) By what analysis methods were the data of the studies examined?

7) How long did it take to perform the studies?

8) What are the learning approaches, methods and techniques used in the studies?

9) What are the measurement and evaluation tools used in the studies?

10) What are the results of the studies?

This study is significant with its implications for further research and guides news studies regarding authentic learning. Based on the study findings, researchers might conduct their studies focusing on process, performance, and results by reflecting the general trends detected in authentic learning.

\section{Methodology}

\subsection{Study design}

This research was conducted with thematic content analysis (meta-analysis). This method includes interpreting subjects from a critical perspective by dividing them into themes or main categories in research on identical topics (Au, 2007). Thematic content analysis is seen as a qualitative method that provides researchers with a rich source of data, as it gives an example of studies by investigating the different qualities of a particular subject (Çalık, Ayas \& Ebenezer, 
2005; Çalık \& Sözbilir, 2014). Simultaneously, this method provides researchers with a free theoretical framework and provides the description of rich, detailed and complexly made-up data (Braun \& Clarke, 2019). Therefore, this method has been preferred for critical interpretation of graduate theses in which authentic learning is evaluated in line with the problem situation in this study.

\subsection{Data collection}

Graduate theses on authentic learning were reached from CoHE National Thesis Center. To reach all the theses, authentic learning, followed by authentic keywords, was used for querying in the database. The studies detected in line with the filtered data were examined primarily to determine the use of authentic learning. In this context, 19 graduate thesis were reached with authentic learning and 187 with the authentic keyword and then these were evaluated. 16 PhDs, 15 master's theses about authentic learning, were encoded to form the research data source (Table 1).

Table 1: The doctoral dissertations and masters' theses under investiagtion

\begin{tabular}{lll|lll}
\hline Reference & Type & Code & Reference & Type & Code \\
\hline Ylldırım (2020) & Doctoral Dissertation & T30 & Sellüm (2020) & Master's Thesis & T28 \\
\hline Ustaoğlu (2020) & Doctoral Dissertation & T31 & Nas (2020) & Master's Thesis & T29 \\
\hline Pullu (2019) & Doctoral Dissertation & T3 & Baştürk (2019) & Master's Thesis & T17 \\
\hline Önger (2019) & Doctoral Dissertation & T9 & Çakır (2019) & Master's Thesis & T21 \\
\hline Karabulut (2018) & Doctoral Dissertation & T6 & Aydın (2019) & Master's Thesis & T25 \\
\hline Aynas (2018) & Doctoral Dissertation & T8 & Özkan (2019) & Master's Thesis & T27 \\
\hline Gündoğan (2017) & Doctoral Dissertation & T1 & Çora (2018) & Master's Thesis & T15 \\
\hline İneç (2017) & Doctoral Dissertation & T13 & Girgin (2018) & Master's Thesis & T26 \\
\hline Karakoç (2016) & Doctoral Dissertation & T2 & Dadlı (2017) & Master's Thesis & T19 \\
\hline Hamurcu (2016) & Doctoral Dissertation & T5 & Alacahan (2016) & Master's Thesis & T18 \\
\hline Aydın Așk (2016) & Doctoral Dissertation & T14 & Güner (2016) & Master's Thesis & T23 \\
\hline Kinay (2015) & Doctoral Dissertation & T7 & Başal (2015) & Master's Thesis & T16 \\
\hline Doğan Dolapçığlu (2015) & Doctoral Dissertation & T10 & Gürdoğan (2014) & Master's Thesis & T24 \\
\hline Yalvaç Hastürk (2013) & Doctoral Dissertation & T4 & Nişancı (2013) & Master's Thesis & T22 \\
\hline Koçyiğit (2011) & Doctoral Dissertation & T12 & Kazancl (2010) & Master's Thesis & T20 \\
\hline Azarmi (2010) & Doctoral Dissertation & T11 & & & \\
\hline
\end{tabular}

\subsection{Data collection tools}

The "Authentic Learning Strategy Checklist" (ALSC) developed by the researchers was used to classify and evaluate in question. This form was developed based on the literature (e.g., Bektaş \& Horzum, 2014; Herrington, 2006; İneç, 2017; Knobloch, 2003; Koçyiğit, 2011). The criteria reflected in ALSC are as follows:

- Finding real-world events,

- Solving real-world problems,

- Involving complex tasks,

- Having different and multiple perspectives,

- Creating a mirroring environment,

- Cooperating between learners,

- Making learners express themselves,

- Going beyond the limits of learning and the determined achievements,

- Structured support and mastery,

- Product-oriented,

- Creating a competitive environment 
- Using authentic evaluation tools,

- Including learning methods and techniques in the process.

The criteria both reflected the nature of authentic learning and determined the state of use as a strategy and provided the sorting of graduate theses. For this reason, it was taken care to reflect all the criteria in the theses that are data sources, even if they are very weak. However, with the application of ALSC, it was observed by experts that these criteria were generally determined as weak.

ALSC was independently implemented by three experts who have carried out studies on educational sciences. One of these experts has carried out studies specifically on authentic learning. After the evaluation process was completed, experts came together and compared the theses and checklists they matched among themselves. Points of consensus and difference of opinion were examined and arrangements were made in this direction. In order to calculate the confidence of the data obtained from ALSC, the confidence form proposed by Miles \& Huberman (1994) in which the calculation of Trust = Consensus / (Consensus + Difference of Opinion) was made was used. As a result, in the evaluation of postgraduate theses detected with ALSC, it was seen that the consensus of the three experts was $83 \%$ similar. This result is considered reliable (Miles \& Huberman, 1994).

\subsection{Data analysis}

Thirty-one graduate theses were examined using a thematic content analysis method. In this context, themes and codes are determined. For the thematic analysis of the research; ten themes were identified as the objectives of the researches, the dependent variables studied, the branches of science in which they were conducted, research patterns, research methods, sample and working groups, analysis methods, research periods, methods and techniques used in the process, measurement and evaluation tools and the results reached, and these themes also formed the parameters of thematic content analysis. After this process, themes and codes were encoded and showed in tables.

\subsection{Validity and trustworthiness}

Graduate theses, which are designated as data sources to ensure no loss in data analysis and the confidence of the research, have been examined independently by researchers. In particular, theses were evaluated one by one through parameters. Thus, the effect of unpredictable variables is minimized. It took two researchers three weeks to study data sources through parameters. A week was spent confirming raw data through code and themes. However, to minimize errors that may occur due to the complex thematic content analysis, the same procedures were repeated by two other independent researchers through three different theses randomly selected from the data source. Then the confidence calculation proposed by Miles \& Huberman (1994) was utilized. The consensus of the four experts was $95 \%$ similar. In addition, this process was carried out in line with an expert who conducted courses on qualitative research methods.

\section{Findings}

In this section, the findings obtained from the thematic content analysis are included in the headings. 


\subsection{Findings on the purposes of the studies examined}

Table 2 presents the purposes of the studies reviewed within the scope of thematic content analysis.

Table 2. Data on the purposes of the studies

\begin{tabular}{llc}
\hline Purposes & Studies & $\boldsymbol{F}$ \\
\hline $\begin{array}{l}\text { Impact of authentic activity-based learning on the relevant } \\
\text { variable }\end{array}$ & $\begin{array}{l}\mathrm{T} 6, \mathrm{~T} 8, \mathrm{~T} 10, \mathrm{~T} 11, \mathrm{~T} 15, \mathrm{~T} 17, \mathrm{~T} 19, \mathrm{~T} 22, \mathrm{~T} 27, \mathrm{~T} 29, \\
\mathrm{~T} 31\end{array}$ & 11 \\
\hline Impact of authentic learning strategy on relevant variable & $\mathrm{T} 4, \mathrm{~T} 5, \mathrm{~T} 9, \mathrm{~T} 13, \mathrm{~T} 24, \mathrm{~T} 25, \mathrm{~T} 26, \mathrm{~T} 28, \mathrm{~T} 30$ & 9 \\
\hline $\begin{array}{l}\text { Impact of authentic task-based learning on the relevant } \\
\text { variable }\end{array}$ & $\mathrm{T} 1, \mathrm{~T} 2, \mathrm{~T} 3, \mathrm{~T} 12, \mathrm{~T} 14, \mathrm{~T} 23$ & 6 \\
\hline $\begin{array}{l}\text { Impact of authentic assessment-based learning on the } \\
\text { relevant variable }\end{array}$ & $\mathrm{T} 7, \mathrm{~T} 16$ & 2 \\
\hline $\begin{array}{l}\text { Authentic knowledge-based learning } \\
\begin{array}{l}\text { Impact of authentic material-based learning on the relevant } \\
\text { variable }\end{array}\end{array}$ & $\mathrm{T} 18, \mathrm{~T} 21$ & 2 \\
\hline
\end{tabular}

As can be seen from Table 2, most of the graduate thesis studies are based on authentic activitybased learning $(f=11)$, authentic learning strategy $(f=9)$ and authentic task-based learning $(f=6)$. Authentic evaluation-based learning of studies carried out for other purposes $(f=2)$, authentic knowledge-based learning $(f=2)$, authentic material-based learning $(f=1)$ and there are few of them.

\subsection{Findings on dependent variables of the studies examined}

Below table shows the dependent variables of the studies.

Table 3. Data on dependent variables of studies

\begin{tabular}{|c|c|c|c|}
\hline & Dependent variables & Studies & $f$ \\
\hline \multirow{4}{*}{ 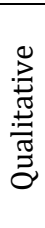 } & Opinions on the process & $\begin{array}{l}\text { T1, T2, T3, T4, T5, T6, T7, T8, T9, T12, T13, T14, T15, T16, T17, T19, } \\
\text { T20, T21, T22, T23, T24, T25, T26, T27, T29 }\end{array}$ & 25 \\
\hline & Local geographic information & $\mathrm{T} 18, \mathrm{~T} 20$ & 2 \\
\hline & $\begin{array}{l}\text { Regulation of the } \\
\text { implementation process }\end{array}$ & T9, T10 & 2 \\
\hline & & Total & 29 \\
\hline \multirow{8}{*}{ 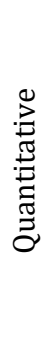 } & Skill & $\begin{array}{l}\text { T3, T4, T5, T7, T8, T10, T12, T14, T15, T17, T19, T23, T27, T28, T29, } \\
\text { T30, T31 }\end{array}$ & 17 \\
\hline & Academic achievement & T2, T3, T6, T8, T11, T12, T13, T19, T22, T25, T27, T29, T30, T31 & 14 \\
\hline & Attitude & T1, T3, T5, T6, T12, T13, T17, T28, T30, T31 & 10 \\
\hline & Persistence & T6, T8, T13, T30 & 4 \\
\hline & Academic self-confidence & T25 & 1 \\
\hline & Motivation & T23 & 1 \\
\hline & Belief & T7 & 1 \\
\hline & & Total & 48 \\
\hline
\end{tabular}

In the graduate thesis studies carried out with a qualitative approach in Table 3 or in which he took part in qualitative approaches, the opinions on the process in particular $(f=25)$; especially skill in the thesis studies where quantitative methods are preferred or included $(f=17)$, academic achievement $(f=14)$ and attitude $(f=10)$. However, it is understood that the studies examining other dependent variables are not very much, but in the studies carried out with qualitative approaches, local geographical information $(f=2)$ and regulation of the implementation process $(f=2)$ in which dependent variables are evaluated; permaneality in studies carried out with quantitative approaches $(f=4)$, academic self-confidence $(f=1)$, motivation $(f=1)$ and faith $(f=1)$. 


\subsection{Findings on the distribution of the studies examined to the branches of science}

The following table includes the branches of science in the studies.

Table 4. Data on the distribution of studies to the branches of science

\begin{tabular}{llc}
\hline Branches of science & Studies & $\boldsymbol{f}$ \\
\hline Science Education & T4, T6, T8, T19, T21, T24, T26, T28, T29, T31 & 10 \\
\hline Social Studies Education & T9, T13, T17, T18, T20, T30 & 6 \\
\hline Mathematics Education & T10, T14, T15, T25, T27 & 5 \\
\hline Foreign Language Education & T2, T11, T22 & 3 \\
\hline Primary Education & T1, T7 & 2 \\
\hline Turkish Education & T5, T23 & 2 \\
\hline Computer and Teaching Technologies Education & T3, T16 & 2 \\
\hline Preschool Education & T12 & 1 \\
\hline
\end{tabular}

In Table 4, the studies are especially in Science Education $(f=10)$ intensified, Social Studies Education $(f=6)$ and Mathematics Education $(f=5)$. However, it is noticeable that the studies carried out in other branches of science are limited. However, in Foreign Language Education $(f=3)$, in Primary Education $(f=2)$, Turkish Education $(f=2)$, Computer and Educational Technologies Education $(f=2)$, in Preschool Education $(f=1)$.

\subsection{Findings on preferred methods and patterns in the studies examined}

The following tables and statements provide the method by which the studies examined by thematic content analysis are carried out and the patterns preferred.

Table 5. Data on preferred methods and patterns in studies

\begin{tabular}{|c|c|c|c|}
\hline Method & Pattern & Studies & $f$ \\
\hline \multirow{9}{*}{ Mixed-Method } & Embedded & T1, T2, T8, T17, T29 & 5 \\
\hline & Unspecified & T7, T13, T22 & 3 \\
\hline & Nested mixed & T23, T28, T30 & 3 \\
\hline & Embedded integrated & T4, T6 & 2 \\
\hline & Explanatory & T5, T27 & 2 \\
\hline & Close-up parallel mixed & T25, T31 & 2 \\
\hline & Exploratory & T3 & 1 \\
\hline & Triangulation & T19 & 1 \\
\hline & & Total & 19 \\
\hline \multirow{2}{*}{ Quantitative } & Quasi-experimental & T11 & 1 \\
\hline & & Total & 1 \\
\hline \multirow{4}{*}{ Qualitative } & Case study & T15, T16, T24, T26 & 4 \\
\hline & Action research & T9, T10, T14, T21 & 4 \\
\hline & Unspecified & T18, T20 & 2 \\
\hline & & Total & 10 \\
\hline \multirow{3}{*}{$\begin{array}{l}\text { Qualitative + } \\
\text { Quantitative }\end{array}$} & Qualitative: Pattern not specified & \multirow{2}{*}{$\mathrm{T} 12$} & \multirow{2}{*}{1} \\
\hline & Quantitative: Quasi-experimental & & \\
\hline & & Total & 1 \\
\hline
\end{tabular}

In Table 5, the work is mostly done by mixed-method $(f=15)$, followed by qualitative methods $(f=10)$. Only quantitative $(f=1)$ and qualitative+quantitative $(f=1)$ it is seen that methods are not preferred much. Embedded in mixed-method studies $(f=5)$, embedded integrated $(f=2)$, exploratory sequence $(f=1)$, explanatory sequence $(f=1)$, nested mixed $(f=3)$, close-up parallel mixed $(f=2)$, triangulation research $(f==1)$ are preferred. In some studies, a mixed-method pattern is not specified $(f=3)$. Only with the quasi-experimental pattern of the work carried out with 
quantitative approaches $(f=1)$; case studies carried out with qualitative approaches $(f=4)$ and action research $(f=4)$. In some studies carried out with qualitative approaches, the preferred pattern could not be determined $(f=2)$. In a study where qualitative and quantitative approaches are used together, the qualitative pattern is not specified and the preferred pattern for the quantitative method is semi-experimental $(f=1)$.

\subsection{Findings on sampling methods of the studies examined}

Below are the tables and descriptions of the studies' sampling methods examined within the scope of thematic content analysis.

Table 6. Data on the sampling method of studies

\begin{tabular}{llc}
\hline Sampling method & Studies & $\boldsymbol{f}$ \\
\hline Purpose sampling & T1, T3, T8, T9, T10, T14, T15, T16, T19, T24, T26, T27 & 12 \\
\hline Random sampling & T2, T4, T5, T6, T7, T12, T13, T17 T18, T21 & 11 \\
\hline Unspecified & T11, T23, T25, T28, T31 & 5 \\
\hline Cluster sampling & T20, T22 & 2 \\
\hline Ordered mixed sampling & T30 & 1 \\
\hline
\end{tabular}

In Table 6, the studies' sampling method is mostly intended for sampling $(f=12)$, followed by random sampling $(f=11)$. Cluster sampling $(f=2)$ with ordered mixed sampling $(f=1)$; however, it is understood that it is not used much. In some studies, the sampling method could not be determined $(f=5)$.

\subsection{Findings on the types of data analysis of the studies examined}

Below are tables and descriptions showing the types of data analysis of studies examined with thematic content analysis.

Table 7. Data on data analysis methods of studies

\begin{tabular}{|c|c|c|c|}
\hline \multicolumn{2}{|c|}{ Data analysis methods } & Studies & $f$ \\
\hline \multirow{7}{*}{ 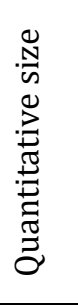 } & t-test & $\begin{array}{l}\text { T1, T3, T4, T6, T7, T8, T11, T12, T13, T19, T22, T23, T25, } \\
\text { T27, T28, T29, T30, T31 }\end{array}$ & 18 \\
\hline & Mann Whitney U & T5, T17, T28 & 3 \\
\hline & Wilcoxon marked queues test & T28, T29 & 2 \\
\hline & Two-way ANOVA & T2 & 1 \\
\hline & One-way Anova & T30 & 1 \\
\hline & Kruskal-Wallis & T16 & 1 \\
\hline & & $\begin{array}{ll}2 & \text { Total } \\
\end{array}$ & 26 \\
\hline \multirow{4}{*}{ 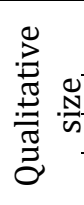 } & Content analysis & $\begin{array}{l}\text { T2, T3, T4, T5, T6, T9, T10, T12, T13, T14, T16, T18, T19, } \\
\text { T20, T22, T24, T25, T26, T27, T29, T30, T31 }\end{array}$ & 22 \\
\hline & Decisive analysis & T1, T5, T7, T8, T15, T17 T23, T24, T28 & 9 \\
\hline & Scoring system* & T21 & 1 \\
\hline & & Total & 32 \\
\hline
\end{tabular}

*It is stated by the author that there is a qualitative type of analysis (Çakır, 2019, p.33).

In Table 7, it is seen that the selection of data analysis types of studies varies according to quantitative and qualitative methods. In quantitative methods, t-test $(f=18)$ is preferred, and at a lesser rate, Mann Whitney U ( $f=3)$, Wilcoxon marked sequences test $(f=2)$, two-way Anova $(f=1)$, one-way Anova $(f=1)$, and Kruskal-Wallis $(f=1)$ types of data analysis are preferred. Within the scope of the qualitative method, content analysis $(f=22)$, followed by decisive analysis $(f=9)$, is understood to have been used. The scoring system $(f=1)$ is noted that is preferred only in one study. 


\subsection{Findings on the implementation periods of the studies examined}

The following tables and statements include the duration of the work examined by thematic content analysis.

Table 8. Data on the duration of the work

\begin{tabular}{lll}
\hline Application time & Studies & $\boldsymbol{f}$ \\
\hline 8 Weeks & $\mathrm{T} 3, \mathrm{~T} 13, \mathrm{~T} 15, \mathrm{~T} 19, \mathrm{~T} 30$ & 5 \\
\hline 5 Weeks & $\mathrm{T} 17, \mathrm{~T} 22, \mathrm{~T} 27$ & 3 \\
\hline 9 Weeks & $\mathrm{T} 8, \mathrm{~T} 24, \mathrm{~T} 31$ & 3 \\
\hline 14 Weeks & $\mathrm{T} 1, \mathrm{~T} 4, \mathrm{~T} 12$ & 3 \\
\hline 6 Weeks & $\mathrm{T} 2, \mathrm{~T} 5$ & 2 \\
\hline 7 Weeks & $\mathrm{T} 14, \mathrm{~T} 28$ & 2 \\
\hline 13 Weeks & $\mathrm{T} 6, \mathrm{~T} 7$ & 2 \\
\hline 10 Weeks & $\mathrm{T} 23$ & 1 \\
\hline 5.5 Weeks & $\mathrm{T} 29$ & 1 \\
\hline 11 Weeks & $\mathrm{T} 9$ & 1 \\
\hline 18 Weeks & $\mathrm{T} 11$ & 1 \\
\hline 24 Weeks & $\mathrm{T} 10$ & 1 \\
\hline 32 weeks & $\mathrm{T} 26$ & 1 \\
\hline 36 Weeks & $\mathrm{T} 21$ & 1 \\
\hline Unspecified & & 3 \\
\hline In Table 8, the studies & \\
\hline
\end{tabular}

In Table 8, the studies lasted mostly eight $(f=5)$, followed by $5(f=3), 9(f=3)$ and $14(f=3)$ it lasts for weeks. $6(f=2), 7(f=2)$ and 13 weeks $(f=2)$ to $5.5(f=1), 10(f=1), 11(f=1), 18(f=1), 24(f=1), 32$ $(f=1)$ and 36 weeks $(f=1)$. Application duration could not be determined in three studies.

3.8. Findings on the methods and techniques used for authentic learning in the studies examined

The following studies, which are examined with thematic content analysis, provide the learning methods and techniques used to perform authentic learning.

Table 9. Data on the approaches, methods and techniques used in the studies

\begin{tabular}{|c|c|c|c|c|}
\hline \multicolumn{2}{|c|}{ Approach, method and technique } & \multirow{2}{*}{$\begin{array}{l}\text { Studies } \\
\mathrm{T} 1, \mathrm{~T} 5, \mathrm{~T} 7, \mathrm{~T} 10, \mathrm{~T} 19, \mathrm{~T} 21, \mathrm{~T} 30\end{array}$} & \multirow{2}{*}{\multicolumn{2}{|c|}{$\frac{f}{7}$}} \\
\hline \multirow{5}{*}{ Method } & Discussion & & & \\
\hline & Show and do & T12 & & 1 \\
\hline & Sample event & T1 & & 1 \\
\hline & Narration & T12 & & 1 \\
\hline & & & Total & 10 \\
\hline \multirow{10}{*}{ Techniques } & Trip & T1, T4, T9, T17, T28, T30, T31 & & 7 \\
\hline & Brainstorming & T1, T3, T5, T8, T12, T28, T31 & & 7 \\
\hline & Q\&A & T1, T14, T28, T30 & & 4 \\
\hline & Role-playing & $\mathrm{T} 1, \mathrm{~T} 4, \mathrm{~T} 8, \mathrm{~T} 12$ & & 4 \\
\hline & Symposium & T6, T7 & & 2 \\
\hline & Drama & T3, T12 & & 2 \\
\hline & Station & $\mathrm{T} 25, \mathrm{~T} 30$ & & 2 \\
\hline & Debate & T17 & & 1 \\
\hline & Open session & $\mathrm{T} 4$ & & 1 \\
\hline & & & Total & 30 \\
\hline \multirow{2}{*}{ Approach } & Scenario & T10, T13, T19, T28, T29, T30, T31 & & 7 \\
\hline & & & Total & 7 \\
\hline \multirow{2}{*}{ Unspecified } & & T2, T11, T15, T16, T18, T20, T22, T23, T24, T26, T27 & & 11 \\
\hline & & & Total & 11 \\
\hline
\end{tabular}


In Table 9, it is seen that learning approaches, methods, and techniques are mostly used in the realization of authentic learning, and in various studies, these are not specified. In studies, they are mostly teaching techniques $(f=30)$, followed by method $(f=10)$ and approaches $(f=11)$. Trips $(f=7)$ and brainstorming $(f=7)$, then question and answer $(f=4)$ to play a role $(f=6)$ technique is used. Symposium $(f=2)$, drama $(f=2)$, station $(f=2)$, debate $(f=1)$, open session (FIt is understood that techniques such as $=1$ ) are also involved in the studies. Discussion of the most commonly used method in studies ( $f=7)$ and then show and do it $(f=1)$, case event $(f=6)$, and plain narration $(f=1)$. The most used approach to authentic learning is scenario-based learning $(f=7)$. In some studies, the approaches, methods, and techniques applied are not specified $(f=11)$.

\subsection{Used in the studies examined measurement and evaluation tools related findings}

The following tables and statements include measurement and evaluation tools used in studies examined with thematic content analysis.

Table 10. Data on measurement and evaluation tools used in studies

\begin{tabular}{|c|c|c|c|}
\hline \multicolumn{2}{|c|}{ Measurement - Evaluation Tools } & Studies & $\boldsymbol{f}$ \\
\hline \multirow{6}{*}{$\underset{\omega}{\stackrel{w}{\omega}}$} & Success test & $\begin{array}{l}\text { T2, T3, T5, T6, T8, T11, T12, T13, T19, T24, T25, T27, T29, T30, } \\
\text { T31 }\end{array}$ & 15 \\
\hline & Skill test & T5, T8, T27, T31 & 4 \\
\hline & Survey & T21, T22 & 2 \\
\hline & Multiple choice test & T14, T16 & 2 \\
\hline & Word association test & T4 & 1 \\
\hline & & $\begin{array}{ll} & \text { Total } \\
\end{array}$ & 24 \\
\hline \multirow{4}{*}{ 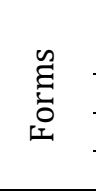 } & Interview form & $\begin{array}{l}\text { T1, T2, T3, T4, T5, T6, T7, T8, T12, T13, T14, T15, T16, T18, T19, } \\
\text { T20, T22, T23, T24, T26, T27, T29, T30 }\end{array}$ & 23 \\
\hline & Personal information form & $\mathrm{T} 1, \mathrm{~T} 9, \mathrm{~T} 12, \mathrm{~T} 13, \mathrm{~T} 23$ & 5 \\
\hline & Evaluation form & $\mathrm{T} 2, \mathrm{~T} 12, \mathrm{~T} 13, \mathrm{~T} 24$ & 4 \\
\hline & & Total & 32 \\
\hline \multirow{8}{*}{$\frac{\tilde{d}}{\tilde{U}}$} & Attitude scale & T1, T3, T5, T6, T8, T12, T13, T17, T19, T28, T30, T31 & 12 \\
\hline & Skill scale & $\mathrm{T} 3, \mathrm{~T} 4, \mathrm{~T} 17, \mathrm{~T} 19, \mathrm{~T} 24, \mathrm{~T} 28, \mathrm{~T} 30$ & 7 \\
\hline & Problem-solving inventory & T3, T7, T12, T29 & 4 \\
\hline & Rubrik & T10 & 1 \\
\hline & Belief scale & T7 & 1 \\
\hline & Self-confidence scale & $\mathrm{T} 25$ & 1 \\
\hline & Motivation scale & $\mathrm{T} 23$ & 1 \\
\hline & & Total & 27 \\
\hline \multirow{6}{*}{ 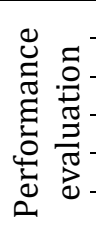 } & Log & T1, T9, T10, T14, T17, T25, T27, T28, T30 & 9 \\
\hline & Observation & T1, T8, T9, T11, T15, T26, T27 & 7 \\
\hline & Student products & T1, T4, T9, T10, T29 & 5 \\
\hline & Multimedia recordings & T9, T10, T15, T18, T30 & 5 \\
\hline & Concept network map & T4 & 1 \\
\hline & & Total & 27 \\
\hline \multirow{3}{*}{ 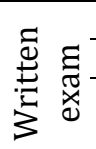 } & Classic quiz & T14 & 1 \\
\hline & Open-ended questions & T31 & 1 \\
\hline & & Total & 2 \\
\hline
\end{tabular}

Tests of measurement evaluation tools used in studies in Table $10(f=24)$, forms $(f=32)$, scales $(f=27)$, performance evaluation $(f=27)$ and written exams $(f=2)$ themes. Of these, a great success under the theme of tests $(f=15)$ test; then skill $(f=4)$, survey $(f=2)$, multiple-choice tests $(f=2)$, word association test $(f=1)$. Under the form theme, you can usually $(f=23)$, then a personal information form $(f=5)$ with evaluation $(f=4)$ forms are evaluated. Under the scales theme, measuring tools are 
very diverse, but largely attitude scales $(f=12)$ are used, followed by skill $(f=7)$ and problemsolving $(f=4)$. It is noted that their inventory is put to work. The scales referenced under the performance evaluation theme are mostly used daily $(f=9)$ observation $(f=7)$ and is; then the student products $(f=5)$ and multimedia recordings are understood to be used. Under this theme, concept maps are also found once $(f=1)$. Under the written exam theme, a classical exam in a study $(f=1)$, one of the open-ended questions $(f=1)$ noted that the resulting working paper is applied.

\subsection{Findings on the results of the studies examined}

Below are tables and descriptions showing the results of studies examined with thematic content analysis.

\section{Table 11. Data on the results of studies}

\begin{tabular}{|c|c|c|c|}
\hline \multicolumn{2}{|c|}{ Results } & \multirow{2}{*}{$\begin{array}{l}\text { Studies } \\
\mathrm{T} 19^{*}, \mathrm{~T} 27^{* *}, \mathrm{~T} 28^{* * *}\end{array}$} & \multirow{2}{*}{$\frac{f}{3}$} \\
\hline$\overline{\widetilde{T}}$ & Impact of authentic learning activities on dependent variables & & \\
\hline$\tilde{z}^{\varpi}$ & & Total & 3 \\
\hline \multirow{7}{*}{$\begin{array}{l}0 \\
: \\
: \\
0 \\
0\end{array}$} & Impact of authentic learning activities on dependent variables & $\begin{array}{l}\text { T6, T8, T10, T11, T15, T17, T19, } \\
\text { T22, T27, T29, T31 }\end{array}$ & 11 \\
\hline & $\begin{array}{l}\text { Impact of authentic learning strategy on the learning } \\
\text { environment }\end{array}$ & T4, T5, T9, T13, T24, T25, T26, T30 & 8 \\
\hline & Impact of authentic task-based activities on dependent variables & $\mathrm{T} 1, \mathrm{~T} 2, \mathrm{~T} 3, \mathrm{~T} 12, \mathrm{~T} 14, \mathrm{~T} 23$ & 6 \\
\hline & $\begin{array}{l}\text { Impact of authentic learning on the local geographic information } \\
\text { acquisition process }\end{array}$ & T18, T20 & 2 \\
\hline & Impact of authentic evaluation process on dependent variables & T7, T16 & 2 \\
\hline & $\begin{array}{l}\text { Impact of authentic material development on the learning } \\
\text { process }\end{array}$ & T21 & 1 \\
\hline & & Total & 30 \\
\hline
\end{tabular}

${ }^{*}$ The author states that positive results have also been achieved regarding academic achievement, environmental attitude, and students' environmental awareness (Dadll, 2017).

** The author found that the success of the students was positively affected (Özkan, 2019)

${ }^{* * *}$ The author also achieved a positive result in one dimension of the attitude scale he used (Sellum, 2020).

In Table 11, the results of the studies are neutral $(f=3)$ and positive $(f=30)$ themes. Under neutral theme, the effect of authentic learning activities on dependent variables does not differentiate $(\mathrm{f}=3$ ); under the positive theme of authentic learning activities on dependent variables $(f=11)$ is mainly positive. Since the dependent variables studied in T19 and T27 are varied, it is understood that some of the results obtained were positive and some were neutral. Under the positive theme of the authentic learning strategy to the learning environment $(f=8)$ and the impact of authentic task-based activities on dependent variables $(f=6)$ is mostly positive. However, the effect of authentic learning on the local geographic information acquisition process $(f=2)$, the effect of the authentic evaluation process on dependent variables $(f=2)$ and the impact of authentic material development on the learning process $(f=1)$ it is not known that it has been positively detected.

\section{Discussion and Conclusion}

This study aims to evaluate the trends in graduate thesis studies on authentic learning in Turkey by analyzing them with a holistic approach. In this context, 31 graduate thesis about authentic learning were reached primarily from the CoHE National Thesis Center database. Since the 
studies' general trends are examined with meta-synthesis, the findings, results, and discussions in this direction reflect the findings of the studies, not the "researchers" own perspectives.

Studies show that authentic learning is most used on an activity-based level in graduate theses and is intended to examine its effect on the relevant variable. This result is followed by evaluating authentic learning as a strategy in studies and the impact of reference to task-based learning on relevant variables. Studies examining the impact of authentic evaluation and authentic materialbased learning on relevant variables and studies on learning based on authentic knowledge are very few. But in line with the literature, authentic learning is expressed as a learning strategy (İneç, 2017; Newmann, Marks \& Gamoran, 1996). Therefore, studies in which authentic learning is considered a learning strategy mainly cover each authentic activity, task, evaluation, materials or knowledge-based learning.

Studies examined the mostly quantitative size of dependent variables; in this context, it is seen that most skills and then academic success and attitude are investigated. Dependent variables such as permaneticy, academic self-confidence, motivation and belief are few. The qualitative dimension of the dependent variables is examined on the views of the process; it is seen that the regulation of the application process with local geographical information is quite limited. This result shows that there is a wide variety of dependent variables that can be affected by authentic learning (İneç, 2020), which is expressed to cover a multidimensional process.

Studies are mostly carried out in Science Education branches, followed by Social Studies Education, Mathematics Education, Foreign Language Education, Primary Education, Turkish Education, Computer and Teaching Technologies Education and Preschool Education. It is understood that authentic learning (Lombardi, 2003), expressed as having a multidisciplinary structure, can be used in all undergraduate programs within this framework. As a matter of fact, authentic learning can be in integration with the disciplines that make up social sciences and science (İneç, 2020).

Mixed-method research designs were adopted most in these studies. In mixed studies, patterns are preferred in the form of mostly embedded, embedded integrated, explanatory, exploratory and triangulation research. In qualitative studies, case studies and action research are mostly used, while some research pattern is not specified. Quasi-experimental studies carried out only with quantitative approaches; In the studies carried out with qualitative+quantitative approaches, the pattern of qualitative size is not specified, and the quantitative dimension is carried out semi-experimentally. Beyond a simple process, authentic learning covers complex and long processes with a real-world context (İneç, 2020). When authentic learning is considered within this framework, evaluating the learning and teaching processes with qualitative and quantitative approaches will facilitate understanding the nature and effects of authentic learning.

The sampling method of the studies is done chiefly with purpose sampling and then by random sampling. The samplings determined by cluster sampling and see ordered mixed sampling are pretty limited. In some studies, the sampling method is not specified. Authentic learning is associated with research skills and creativity. Students thus experience the real world (Renzulli, 1997). Reaching these students is mostly through teachers who want to be involved in this complex process. Therefore, methods such as purpose sampling are preferred in this framework. In the studies involving teachers later, school, teacher and student preference is determined randomly. In this type of research, the teacher and the student's situation assimilate the authentic learning process is very important. 
In studies, data analysis types, especially under the qualitative approach, are more preferred. In this context, content analysis is mostly one of the data analysis methods applied after the descriptive analysis. It was determined that a method expressed as a scoring system was used in a single study. In studies, t-testing within the quantitative approach framework is the most used data analysis method, while reference to methods such as Mann Whitney U, Wilcoxon marked sequences test, single and two-factor ANOVA and Kruskal-Wallis are limited. It is expected that versatile measurement tinges will be used naturally in the performance assessment (Birgin \& Küçük, 2012), which deals with whether meaningful learning, especially within the framework of authentic context, achieves the intended goals in real life.

Studies usually last eight weeks. There are also unspecified studies with applications lasting 36 weeks. This result is that the process, expressed as authentic learning, extends over a wide period rather than a short period; this is caused by the necessity of implementing meaningful learning into the real world within the framework of authentic context and continuous evaluation of it (Baron, 1991).

In order to perform authentic learning in studies, teaching techniques are mostly applied and then teaching methods are applied to work. There are also studies that apply to learning approaches, but some do not contain it. Most of the teaching techniques are brainstorming and trips, followed by question-answer and role play, followed by teaching techniques such as symposium, drama, station, debate and an open session. As teaching methods, it is mostly the method of discussion; it is seen that there is a limited number of demonstrations, exemplary events, and straight narrations. The identified learning approach is only scenario-based learning and is included in some of the studies; in some studies, no approach, method or technical knowledge is specified. There are standards prescribed by Newmann, Marks \& Gamoran (1995) in reflecting authentic learning into learning environments. In this context, various approaches, methods, and techniques should be applied in case authentic learning can be used as a strategy in the classroom and beyond (Bektaş \& Horzum, 2014, pp. 83-90; İneç, 2017; İneç, 2020, pp. 31-36; İneç \& Akpınar, 2017; Önger, 2019).

In studies, forms, scales and performance evaluation tools, tests and a very limited number of written exams are mostly used as measurement evaluation tools. In terms of forms, most interview forms are included, and then there are personal information and evaluation forms. Most attitudes on the scales are followed by skill, problem-solving, rubric, faith, self-confidence, and motivational scales, respectively. In performance evaluation, the most logs, followed by observation, student products, multimedia recordings and concept network maps, are preferred. The tests mostly have success tests, followed by skills, surveys, multiple-choice tests and word association tests. In written exams, classical exams and open-end questions are used in a limited way. Expressed as one of the components of authentic learning, authentic evaluation (Herrington, 2006) is fully interested in the learning process beyond classical measurement tools. It is trying to measure the transfer of learning to the real world at this stage, focusing on the process (Karakuş, 2006). Tools that can be used within the framework of authentic evaluation are shown product files, performance tasks, projects, checklists and graded scoring keys (Bektaş \& Horzum, 2014). In the studies, it is understood that these tools are mostly used, but the necessity of using tools such as testing, which is considered as classic measurement tools due to the pre-academic success in our education system, is reflected in the studies.

Most of the studies achieve positive results, and a limited number achieve neutral results. Much of the positive results belong to authentic learning activities, followed by studies exploring the impact of authentic learning strategy, authentic task-based activities, authentic evaluation 
process on dependent variables, and the learning process of authentic learning and material development. Neutral results were found in studies examining the impact of authentic learning activities on dependent variables. However, some positive results were reached in these studies. There was no research having a negative conclusion. These findings highlight the power of authentic learning in creating real-life contexts and meaningful learning.

It is expected that the study findings regarding the examination of graduate studies on authentic learning with a holistic approach will guide and shed light on further studies on authentic learning in the Turkish context.

\section{References}

$\mathrm{Au}, \mathrm{W}$. (2007). High-stakes testing and curricular control: A qualitative meta-synthesis. Educational Researcher, 36, 258-267.

Aynas, N. (2018). Fen bilimleri dersinde otantik öğrenme uygulamalarının etkisinin incelenmesi (Yayımlanmamış Doktora Tezi). Eğitim Bilimleri Enstitüsü, Van.

Baron, J.B. (1991). Performance assessment: blurring the edges of assessment, curriculum and instruction. G. Kulm and S.M. Malcom, (Ed.), In Science assessment in the service of reform (pp. 247-266). Washington: American Association for the Advancement of Science.

Bektaş. M. \& Horzum, M. B. (2014). Otantik Öğrenme. Ankara: Pegem Akademi.

Birgin, O. \& Küçük, M. (2012). Alternatif ölçme ve değerlendirme araç ve yöntemleri. M. Küçük \& Y. Geçit, (Ed.), In Eğitimde ölçme ve değerlendirme(pp. 159-220). Ankara: Nobel Yayın Dağıtım.

Braun, V. \& Clarke, V. (2019). Use of thematic analysis in psychology. S. N. Şad, N. Özer \& A. Atli (Çev.Edt.). Eğitimde Nitel Araştırmalar Dergisi - Journal of Qualitative Research in Education, 7(2), 873-898. doi: 10.14689/issn.2148-2624.1.7c.2s.17m.

Callison, D. \& Lamb, A. (2004). Keywords in instruction: Authentic learning. School Library Monthly, 21(4), 34-39.

Çalık, M., Ayas, A. \& Ebenezer, J. V. (2005). A review of solution chemistry studies: Insights into students' conceptions. Journal of Science Education and Technology, 14(1), 29-50. DOI:10.1007/s10956- 005-2732-3

Çalık, M. \& Sözbilir, M. (2014). İlköğretim düzeyinde yapılan argümantasyon çalışmalarına yönelik tematik içerik analizi. Eğitim ve Bilim, 42(190), 281-303. DOI:10.15390/eb.2017.6845.

Dadlı, G. (2017). Insan ve çevre iliş̧kileri ünitesinde otantik probleme dayalı öğrenme etkinliklerinin 7. sınıf ögrrencilerinde yansitıcı düşünme becerisi, akademik başarı, çevre tutum ve farkındalıkları üzerine etkisi. (Yayımlanmamış Yüksek lisans tezi). Kahramanmaraş Sütçü İmam Üniversitesi Fen Bilimleri Enstitüsü, Kahramanmaraş.

Herrington, J. (2006). Authentic e-learning in higher education: Design principles for authentic learning environments and tasks. World Conference on E-Learning in Corporate, Government, Healthcare, and Higher Education, Chesapeake, Va.

İneç, Z. F. \& Akpınar, E. (2017). Sosyal bilgilerin otantik öğretiminde yeni yaklaşımlar. Uluslararası Sosyal Alan Araştırmaları Dergisi, 6(2), 46-65.

İneç, Z. F. (2017). Sosyal bilgiler dersinde geo-medya destekli otantik öğrenme ortamının öğrenmeye etkisi. (Yayımlanmamış Doktora tezi). Erzincan Üniversitesi Sosyal Bilimler Enstitüsü, Erzincan.

İneç, Z. F. (2020). Otantik öğrenme. Kozikoğlu, i. (Ed.), Eğitimde güncel yaklaşımlar, içinde (ss.1736). Ankara: Pegem Akademi.

İneç, Z. F. (2021). Otantik öğrenme modeli. Polat, S. \& Aksoy, B. (Ed.), In Kuramdan uygulamaya sosyal bilgiler öğretiminde çağdaş öğrenme ve öğretme yaklaşımları(pp.93-114). Ankara: Pegem Akademi.

Karakuş, F. (2006). Sosyal bilgiler öğretiminde yapıcı öğrenme ve otantik değerlendirme yaklaşımlarının öğrencilerin akademik başarı, kalıcılık ve sosyal bilgiler dersine yönelik 
tutumlarına etkisi. (Yayımlanmamış Doktora tezi). Çukurova Üniversitesi Sosyal Bilimler Enstitüsü, Adana.

Knobloch, N. A. (2003). Is experiential learning authentic? Journal of Agricultural Education, 44(4), 22-34. Doi: 10.5032/jae.2003.04022

Koçyiğit, S. (2011). Otantik görev odaklı yapılandırmacı yaklaşımın öğretmen adaylarının başarılarına, derse karşı tutumlarına ve problem çözme becerilerine etkisi (Yayımlanmamış Doktora tezi). Eğitim Bilimleri Enstitüsü: İstanbul.

Koçyiğit, S. \& Zembat, R. (2013). Otantik görevlerin öğretmen adaylarının başarılarına etkisi. Hacettepe Üniversitesi Eğitim Fakültesi Dergisi, 28(3). 291-303.

Lombardi, M. M. (2007). Authentic learning for the 21st century: An overview. Educause Learning Initiative, 1, 1-12. Ministry of National Education [MoNE], (2018). Social studies course curriculum. Retrieved from http://mufredat.meb.gov.tr/Dosyalar/ 201812103847686 SOSYAL\%20B\%C4\%B0LG\%C4\%B0LER\%20\%C3\%96\%C4\%9ERET \%C4\%B0M\%20PROGRAMI\%20.pdf.

Miles, M.B. \& Huberman, A.M. (1994). Qualitative data analysis: an expanded sourcebook (2 Ed.). California: SAGE Publications.

Newmann, F.M., Marks, H.M. \& Gamoran, A. (1995). Authentic pedagogy: standards that boost student performance. Issue in Restructuring Schools, 8,2-17. ERIC Number: ED39090

Newmann, F.M., Marks, H.M. \& Gamoran, A. (1996). Authentic pedagogy and student performance. American Journal of Education, 104(4). 280-312.

Önger, S. (2019). Sosyal bilgiler öğretiminde otantik öğrenme yaklaşımı: bir eylem araştırması (Yayımlanmamış Doktora tezi). Gazi Üniversitesi Eğitim Bilimleri Enstitüsü, Ankara.

Özer, B. (2008). Öğrenmeyi Öğretme. Hakan, A (Ed.), Öğretmenlik meslek bilgisi alanındaki yenilikler, içinde (pp.147-164). Eskişehir: Anadolu Üniversitesi Yayınları.

Özkan, T. (2019). Otantik etkinliklerin 7. Sinıf öğrencilerinin oran orantı konusundaki akademik başarılarına ve bilimsel süreç becerilerine etkisi (Yayımlanmamış Yüksek lisans tezi). Hatay Mustafa Kemal Üniversitesi Sosyal Bilimleri Enstitüsü, Hatay.

Renzulli, J. S. (1997). How to develop an authentic enrichment cluster. The National Research Center on the Gifted and Talented University of Connecticut. Uconn. Retrieved from https://gifted.uconn.edu/schoolwide-enrichmentmodel/authentic_enrichment_cluster/.

Senemoğlu, N. (2015). Gelişim, öğrenme ve öğretim. Ankara: Yargı Yayınevi.

Sellüm, F. S. (2020). Fen bilimleri dersinde otantik öğrenme uygulamalarının öğrencilerin karar verme becerilerine ve bu derse yönelik tutumlarına etkisi (Yayımlanmamış Yüksek lisans tezi). Sakarya Üniversitesi Eğitim Bilimleri Enstitüsü, Sakarya.

Terry, W. S. (2009). Learning and memory, basic principles, processes and procedures. Pearson Education.

Turkish Language Association [TLA], (2020). Authentic. Turkish Language Association's Contemporary Turkish Dictionary. Retrieved from https://sozluk.tdk.gov.tr. 


\section{Appendix 1: Thesis Examined within the Scope of Thematic Content Analysis}

Alacahan, G. (2016). Otantik öğrenmede yerel coğrafi bilgi ve halk takvim (Yayımlanmamış Yüksek lisans tezi). Adnan Menderes Üniversitesi Sosyal Bilimler Enstitüsü, Aydın.

Aydın, O. (2019). Otantik öğrenme ortamlarının 4. Sınıf matematik ders bașarısı ve akademik özgüvenlerine etkisi (Yayımlanmamış Yüksek lisans tezi). Burdur Mehmet Akif Ersoy Üniversitesi Eğitim Bilimleri Enstitüsü, Burdur.

Aydın Aşk, Z. (2016). Matematik dersinde otantik görev odaklı öğrenme süreçlerinin incelenmesi: Bir eylem araştırması (Yayımlanmamış doktora tezi). Gaziantep Üniversitesi Eğitim Bilimleri Enstitüsü, Gaziantep.

Aynas, N. (2018). Fen bilimleri dersinde otantik öğrenme uygulamalarının etkisinin incelenmesi (Yayımlanmamış Doktora Tezi). Van Yüzüncü Yıl Üniversitesi Eğitim Bilimleri Enstitüsü, Van.

Azarmi, S. (2010). The use of authentic games in english language teaching (Yayımlanmamıs Doktora tezi). Gazi Üniversitesi Eğitim Bilimleri Enstitüsü, Ankara.

Başal, F. (2015). Bilgi ve iletişim teknolojileri becerilerini ölçen çoktan seçmeli, otantik ve simülasyon tabanlı değerlendirme yöntemlerine ilişkin öğrenci görüşleri (Yayımlanmamış Yüksek lisans tezi). Uludağ Üniversitesi Eğitim Bilimleri Enstitüsü, Bursa.

Baştürk, G. (2019). Otantik öğrenme uygulamalarının öğrencilerin eleștirel düşünme becerileri ve sosyal bilgiler dersine yönelik tutumlarına etkisi (Yayımlanmamış Yüksek lisans tezi). Sakarya Üniversitesi Eğitim Bilimleri Enstitüsü, Sakarya.

Çakır, H. (2019). Ortaokul öğrencilerinin biyolojik çeşitlilik konusunda bilgi düzeylerini arttırmak için otantik öğrenme temelli materyal tasarımı ve değerlendirilmesi (Yayımlanmamış Yüksek lisans tezi). Balıkesir Üniversitesi Fen Bilimleri Enstitüsü, Balıkesir.

Çora, A. (2018). Ortaokul yedinci sınıf öğrencilerinin otantik matematiksel modelleme etkinlikleri ile problem çözme becerilerinin incelenmesi (Yayımlanmamış Yüksek lisans tezi). Eskişehir Osmangazi Üniversitesi Eğitim Bilimleri Enstitüsü, Eskişehir.

Dadlı, G. (2017). Insan ve çevre iliş̧kileri ünitesinde otantik probleme dayalı öğrenme etkinliklerinin 7. Sinıf öğrencilerinde yansıtıcı düşünme becerisi, akademik başarı, çevre tutum ve farkındalıkları üzerine etkisi (Yayımlanmamış Yüksek lisans tezi). Kahramanmaraş Sütçü İmam Üniversitesi Fen Bilimleri Enstitüsü, Kahramanmaraş.

Doğan Dolapçıŏlu, S. (2015). Matematik dersinde otantik öğrenme yoluyla eleștirel düşünme becerisinin geliştirilmesi: bir eylem araştırması (Yayımlanmamış Doktora tezi). Çukurova Üniversitesi Sosyal Bilimler Enstitüsü, Adana.

Girgin, Ș. (2018). Ethnographic case study of early stem education: investigating students' authentic learning experiences (Yayımlanmamış Yüksek lisans tezi). Yıldız Teknik Üniversitesi Doğal ve Uygulamalı Bilimler Enstitüsü, İstanbul.

Güner, M. (2016). Türkçe dersinde otantik görev temelli otantik materyal kullanımının öğrencilerin okuduğunu anlama, yazma becerileri ve yazma motivasyonları üzerindeki etkisi (Yayımlanmamış Yüksek lisans tezi). Anadolu Üniversitesi Eğitim Bilimleri Enstitüsü, Eskișehir.

Gündoğan, A. (2017). Hayat bilgisi dersinde otantik görev temelli öğrenme ortamlarını öğrencilerin derse yönelik tutumlarına ve öğrenme süreçlerine yansıması (Yayımlanmamış Doktora tezi). Eskişehir Anadolu Üniversitesi Eğitim Bilimleri Enstitüsü, Eskişehir.

Gürdoğan, M. (2014). Sınıf öğretmeni adaylarının otantik öğrenme yaklașımının uygulanabilirliği ile ilgili görüșleri: fen ve teknoloji laboratuvar uygulaması örneği (Yayımlanmamış Yüksek lisans tezi). Akdeniz Üniversitesi Eğitim Bilimleri Enstitüsü, Antalya.

Hamurcu, G. C. (2016). İlköğretim 7. Sinıf Türkçe dersinde otantik öğrenmenin öğrencilerin problem çözme ve okuduğunu anlama becerileri ile derse iliş̧kin tutumlarına etkisi (Yayımlanmamış Doktora tezi). İnönü Üniversitesi Eğitim Bilimleri Enstitüsü, Malatya.

İneç, Z. F. (2017). Sosyal bilgiler dersinde geo-medya destekli otantik öğrenme ortamının öğrenmeye etkisi. (Yayımlanmamış Doktora tezi). Erzincan Üniversitesi Sosyal Bilimler Enstitüsü, Erzincan.

Karabulut, H. (2018). Teknoloji destekli otantik öğrenme aktivitelerinin ögrrencilerin fen öğrenmelerine, fene yönelik tutumlarına ve bilgilerinin kalıcılığına etkisi (Yayımlanmamış Doktora tezi). Gazi Üniversitesi Eğitim Bilimleri Enstitüsü, Ankara.

Karakoç, B. (2016). Otantik görev odaklı uygulamaların yabancı dil eğitimine etkisinin incelenmesi (Yayımlanmamış Doktora tezi). Gaziantep Üniversitesi Eğitim Bilimleri Enstitüsü, Gaziantep.

Kazancı, H. (2010). Otantik öğrenme açısından yerel coğrafi bilgi (Artova örneği) (Yayımlanmamış Yüksek lisans tezi). Gaziosmanpaşa Üniversitesi Sosyal Bilimler Enstitüsü, Tokat.

Kinay, İ. (2015). Otantik değerlendirme yaklaşımının öğretmen adaylarının problem çözme becerileri ile öğrenmeye ve katılımcı değerlendirmeye yönelik inançlarına etkisinin incelenmesi (Yayımlanmamış Doktora tezi). Gaziantep Üniversitesi Eğitim Bilimleri Enstitüsü, Gaziantep.

Koçyiğit, S. (2011). Otantik görev odaklı yapılandırmacı yaklaşımın öğretmen adaylarının başarılarına, derse karşı tutumlarına ve problem çözme becerilerine etkisi (Yayımlanmamış Doktora tezi). Marmara Üniversitesi Eğitim Bilimleri Enstitüsü, İstanbul.

Nas, C. (2020). Otantik öğrenme yaklaşımına dayalı araştırma ve sorgulama temelli etkinliklerin 5. Sınıf öğrencilerinin akademik başarılarına ve yaratıcı problem çözme özelliklerine etkisinin incelenmesi (Yayımlanmamış Yüksek lisans tezi). Marmara Üniversitesi Eğitim Bilimleri Enstitüsü, İstanbul. 
Nişancl, İ. (2013). Using authentic songs to teach english: an analysis of students' perceptions (Yayımlanmamış Yüksek lisans tezi). Dicle Üniversitesi Eğitim Bilimleri Enstitüsü, Diyarbakır.

Önger, S. (2019). Sosyal bilgiler öğretiminde otantik öğrenme yaklaşımı: bir eylem araştırması (Yayımlanmamış Doktora tezi). Gazi Üniversitesi Eğitim Bilimleri Enstitüsü, Ankara.

Özkan, T. (2019). Otantik etkinliklerin 7. Sinıf öğrencilerinin oran orantı konusundaki akademik başarılarına ve bilimsel süreç becerilerine etkisi (Yayımlanmamış Yüksek lisans tezi). Hatay Mustafa Kemal Üniversitesi Sosyal Bilimleri Enstitüsü, Hatay.

Pullu, E. K. (2019). Programlama öğretiminde otantik görev odaklı uygulamaların öğrencilerin akademik başarısına, tutumlarına, problem çözme ve yaratıcı düşünme becerilerine etkisi (Yayımlanmamış Doktora tezi). Fırat Üniversitesi Eğitim Bilimleri Enstitüsü, Elâzı̆̆.

Sellüm, F. S. (2020). Fen bilimleri dersinde otantik öğrenme uygulamalarının öğrencilerin karar verme becerilerine ve bu derse yönelik tutumlarına etkisi (Yayımlanmamış Yüksek lisans tezi). Sakarya Üniversitesi Eğitim Bilimleri Enstitüsü, Sakarya.

Ustaoğlu, M. (2020). “Vücudumuzun bilmecesini çözelim” ünitesinde otantik öğrenme etkinliklerinin 5. Sinıf öğrencilerinin ögrenme ürünlerine etkisi (Yayımlanmamış Doktora tezi). On Dokuz Mayıs Üniversitesi Eğitim Bilimleri Enstitüsü, Samsun.

Yalvaç Hastürk, H. G. (2013). Öğretmen adaylarının bazı çevre konularına ilişsin zihinsel yapılarındaki değişim otantik ögrenme ortamlarında incelenmesi ve değerlendirilmesi (Yayımlanmamıș Doktora tezi). Gazi Üniversitesi Eğitim Bilimleri Enstitüsü, Ankara.

Yıldırım, R. (2020). Otantik öğrenme yaklașımının sosyal bilgiler dersinde uygulanması: bir karma yöntem araștırması (Yayımlanmamış Doktora tezi). Afyon Kocatepe Üniversitesi Sosyal Bilimler Enstitüsü, Afyonkarahisar.

\section{Etik Beyannamesi}

$\mathrm{Bu}$ makalede "Yükseköğretim Kurumları Bilimsel Araştırma ve Yayın Etiği Yönergesi" kapsamında belirtilen bütün kurallara uyduğumuzu, "Bilimsel Araștırma ve Yayın Etiğine Aykırı Eylemler" başlığı altında belirtilen eylemlerden hiçbirini gerçekleştirmediğimizi, hiçbir çıkar çatışmasının olmadığını ve oluşabilecek her türlü etik ihlalinde sorumluluğun makale yazarlarına ait olduğunu beyan ederiz.

Research article:İneç, Z. F., \& Bozkurt, Y. (2021). Thematic content analysis of graduate studies on authentic learning in Turkey. Erzincan University Journal of Education Faculty, 23(2), 575-592. 